\title{
Air Assimilative Capacity for Sulfur Dioxide and Nitrogen Dioxide: Case Study the Eastern Region of Thailand
}

\author{
Jaeraya Ruangkawsakun and Sarawut Thepanondh
}

\begin{abstract}
The assimilative capacity of the Eastern region, Thailand is estimated by using ventilation coefficient data and air quality model. Box model is used to predict the spatial and temporal distribution of two pollutants namely $\mathrm{SO}_{2}$ and $\mathrm{NO}_{2}$. Meteorological characteristic of the study area in the year 2010 was selected in the analysis. The results indicated that Tha-Takiap, Chachaengsao was the highest assimilative capacity of $\mathrm{SO}_{2}$ and $\mathrm{NO}_{2}$. Temporal variation of assimilative capacity of air pollution in the study area in which the highest carrying capacity was in November.
\end{abstract}

Index Terms-Air assimilative capacity, air quality model, ventilation coefficient.

\section{INTRODUCTION}

Development of industry significantly contributes to regional economic growth. However, Industrial development is one of the important causes of environmental problems which can be minimized if industrial development planning is done keeping in view the environmental considerations. At present, Industrial siting is being mainly planned keeping in view the raw material availability, access to the market, transport facilities and other related economic considerations without paying enough attention to environmental aspects, which are normally accepted as one of the significant criteria for siting of new industries. Improper siting of industries can seriously affect the environmental quality. Site selection based on environmental criteria with the purpose of minimizing adverse environmental impacts is a vital prerequisite. This is especially important when the proposed industry is air pollution in nature [1].

The Eastern region of Thailand is the most industrially developed region especially chemical industry and power plant which is important air pollution sources such as sulfur dioxide $\left(\mathrm{SO}_{2}\right)$ and nitrogen dioxide $\left(\mathrm{NO}_{2}\right)$ [2]. Pollution control focus on emission loads from the source that can be released will not exceed emission standard. The main point of pollution control management, although emission of all factories does not exceed the standard, the pollution emitted into the atmosphere excess air quality standards or not. (The area also has the atmospheric assimilation potential or not.)

The assimilative capacity of atmosphere is estimated through dispersion models in terms of concentration of pollutants. Box Model, dispersion models for area sources, is used to predict the spatial and temporal distribution of two pollutants namely $\mathrm{SO}_{2}$ and $\mathrm{NO}_{2}$. Details of this approach are presented through a case study carried out for the Eastern

Manuscript received August 15, 2013; revised September 27, 2013.

The authors are with the Department of Sanitary Engineering, Faculty of Public Health, Mahidol University, Bangkok 10400 Thailand (e-mail: r.jaeraya@gmail.com, sarawut.the@mahidol.ac.th). region of Thailand. The air assimilative capacity environment is defined as the maximum amount of pollution load that can be discharged without violating the best designated use of the air emission resource in the planning region [3]. In this study, ventilation coefficient (mixing height and wind speed) is used as major meteorological input in the analysis.

\section{RESEARCH DESIGN}

This research aimed to estimate atmospheric assimilation potential in a district level for Eastern region of Thailand by using ventilation coefficient data and air quality model. Meteorological characteristic of the study area in the year 2010 was selected in the analysis. Carrying capacity of $\mathrm{SO}_{2}$ and $\mathrm{NO}_{2}$ were evaluated by using box model analysis.

\section{DATA COLLECTION}

\section{A. Study Area}

The study domain covered the Eastern region of Thailand (about $34,475 \mathrm{~km}^{2}$ ). The Eastern region consists of the 7 provinces as follows:

1) Chonburi

2) Rayong

3) Chanthaburi

4) Trat

5) Chachaengsao

6) Prachinburi

7) Sa Kaeo

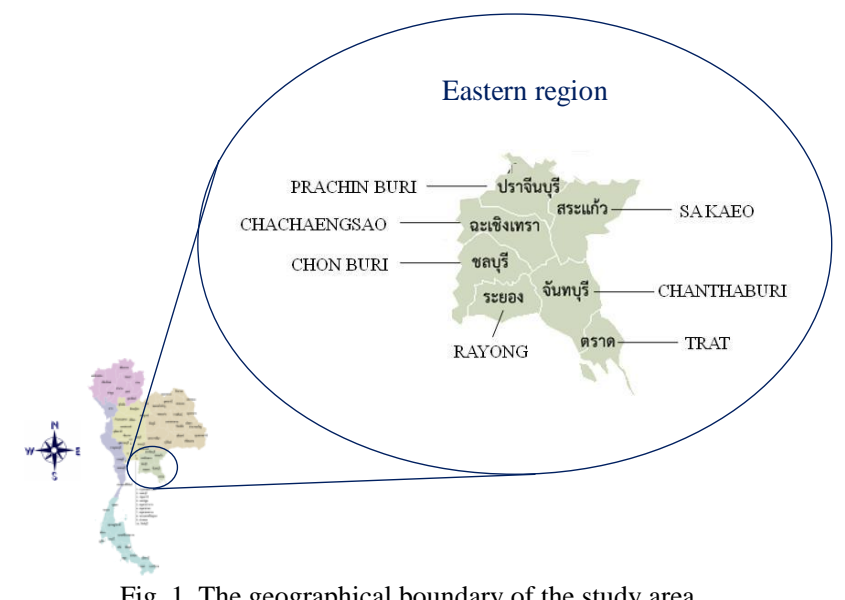

Spatial data on a district level from each province were collected and used in the analysis. These data were achieved from GIS data, obtained from the Department of Provincial Administration, Ministry of Interior. The data used in the 
analysis were total area of the district and the length of district as measured in the northeast-southwest direction. The geographical boundary of the study area is as shown in Fig. 1.

\section{B. Air pollutants Concentration Data}

Air pollution is the presence of undesirable material in air, in quantities large enough to produce harmful effects. The undesirable materials may damage human health, vegetation, human property, or the global environment as well as create aesthetic insults in the form of brown or hazy air or unpleasant smells [7].

Most industry of the Eastern region of Thailand is chemical industry and power plant which is important air pollution sources especially $\mathrm{SO}_{2}$ and $\mathrm{NO}_{2}$. Therefore, the two air pollutants were studied in this research.

$\mathrm{SO}_{2}$ and $\mathrm{NO}_{2}$ ambient concentration measured in the year 2010-2012 from air quality monitoring station located in the Eastern region of Thailand were used in this study. These data were obtained from Pollution Control Department, Ministry of Natural Resources and Environment.

\section{Meteorological Data}

Wind speed and mixing height data which were used to calculated for ventilation coefficient were derived from a project carried out by Thepanondh in the year 2013 [4]. These data were predicted by using the WRF model. The spatial resolution of each grid cell was $50 \times 50 \mathrm{~km}^{2}$ covering the entire area of study domain as show in Fig. 2.

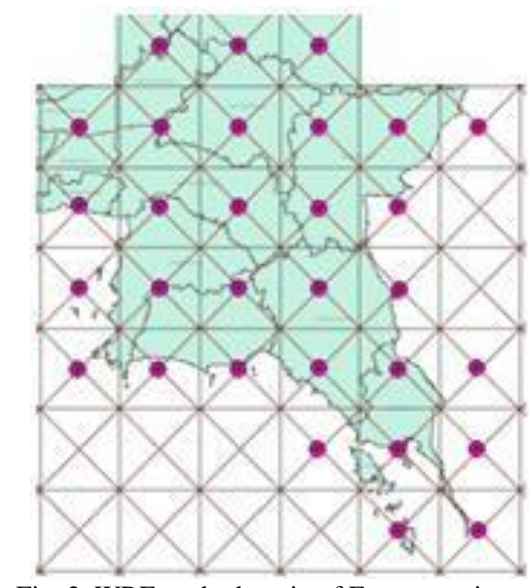

Fig. 2. WRF study domain of Eastern region.

Wind speed and mixing height from WRF Model were used to calculate for ventilation coefficient by using equation (1)

$$
\operatorname{VC}\left(\mathrm{m}^{2} / \mathrm{s}\right)=\text { Wind speed }(\mathrm{m} / \mathrm{s}) \times \text { Mixing height }(\mathrm{m})
$$

Spatial analysis of ventilation coefficient was carried out by using the Geographical Information System (GIS). This data were further used to calculate for assimilative capacity of air pollution of the study area in this study.

\section{BOX MODEL}

Box model has been used in environmental research. For example, carbon monoxide concentrations were monitored in a deep street canyon and were modelled using a two-box model [5]. Another research applies a fixed box model to calculate the temporal variance of the concentration of PM10 in Thanh Xuan District, Hanoi [6].

The box model computes the air pollution concentration using general mass balance analysis principle. The model was used to estimate maximum emission load of area [7], by using this equation (2)

$$
c=b+\frac{q L}{u H}
$$

where

$$
\begin{aligned}
& c=\text { Pollutant concentration }\left(\mathrm{g} / \mathrm{m}^{3}\right) \\
& b=\text { Background pollutant concentration }\left(\mathrm{g} / \mathrm{m}^{3}\right) \\
& q=\text { Emission load }\left(\mathrm{g} / \mathrm{s} \quad \mathrm{m}^{2}\right) \\
& L=\text { Length of area }(\mathrm{m}) \\
& u=\text { Wind speed }(\mathrm{m} / \mathrm{s}) \\
& H=\text { Mixing height }(\mathrm{m})
\end{aligned}
$$

The pollutant concentration $(c)$ was set equal to 1 hour ambient air quality standard. Therefore, $\mathrm{SO}_{2}$ was set as 780 $\mathrm{ug} / \mathrm{m}^{3}$. As for $\mathrm{NO}_{2}$ concentration; this value was set as 320 $\mathrm{ug} / \mathrm{m}^{3}$.

Background concentrations $(b)$ of $\mathrm{SO}_{2}$ and $\mathrm{NO}_{2}$ were set as ninety-five percentile of the measured concentration of this parameter in the area. Data used in analysis were from 2010 to 2012. $\mathrm{SO}_{2}$ was set as $26.07 \mathrm{ug} / \mathrm{m}^{3}$. As for $\mathrm{NO}_{2}$ concentration; this value was set as $50.59 \mathrm{ug} / \mathrm{m}^{3}$.

The ventilation coefficient which was calculated by multiplying wind speed and mixing height data were similar with the value, used in the box model equation ( $u$ and $H$ ). Therefore an emission load of pollutant could be calculated when background concentration, pollutant concentration and the length of area were known.

\section{RESUlTS AND DisCUSSIONS}

\section{A. $\mathrm{SO}_{2}$ Emission Load}

Results from the box model analysis indicated that there were spatial and temporal variations of carrying capacity of $\mathrm{SO}_{2}$ emission in the study area.

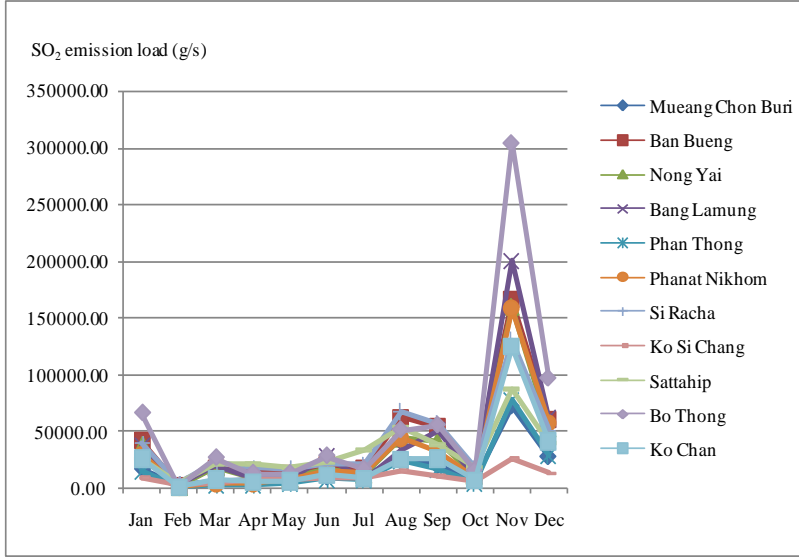

Fig. 3. $\mathrm{SO}_{2}$ Emission load of Chonburi.

In general, it was found that Chachaengsao province has the highest assimilative capacity of $\mathrm{SO}_{2}$ as compared with other provinces. Temporal variation of the highest assimilative capacity was occurred in November. Details were as shown in Fig. 3- Fig. 9. 


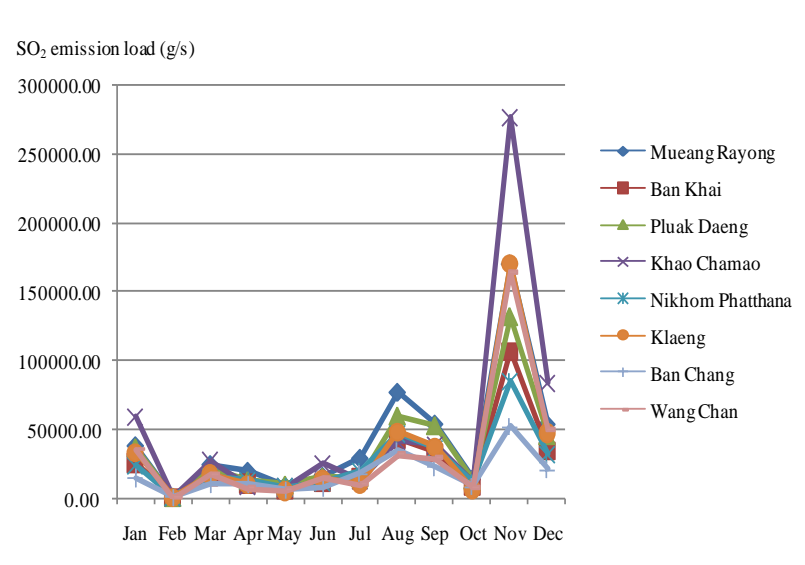

Fig. 4. $\mathrm{SO}_{2}$ Emission load of Rayong.

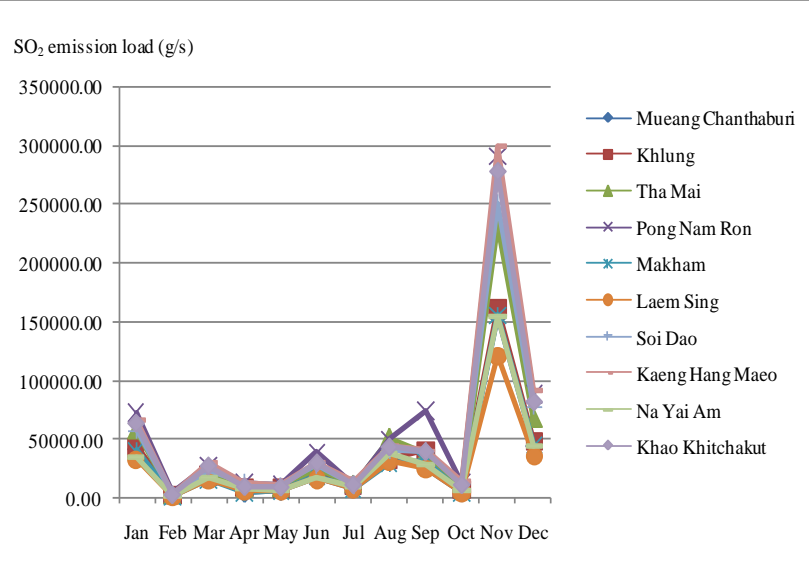

Fig. 5. $\mathrm{SO}_{2}$ Emission load of Chanthaburi.

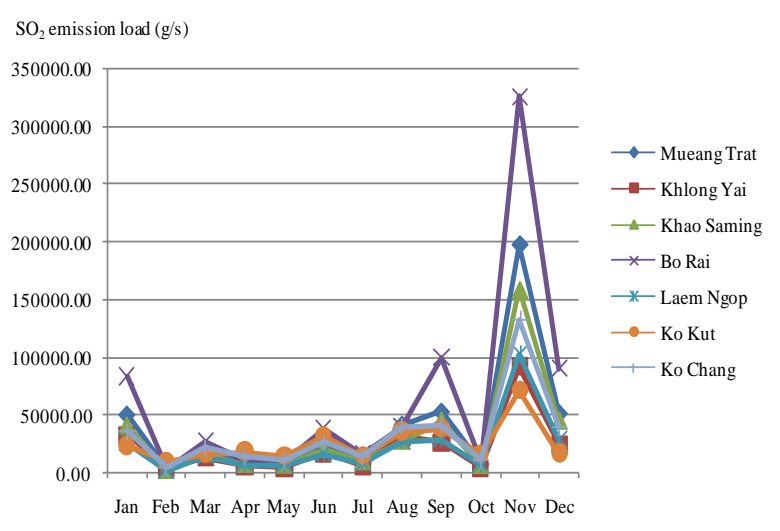

Fig. 6. $\mathrm{SO}_{2}$ Emission load of Trat.

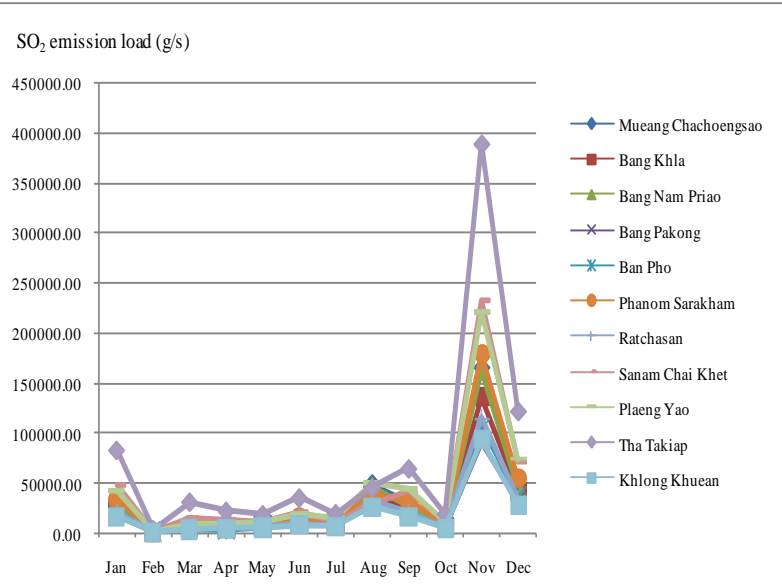

Fig. 7. SO2 Emission load of Chachaengsao.

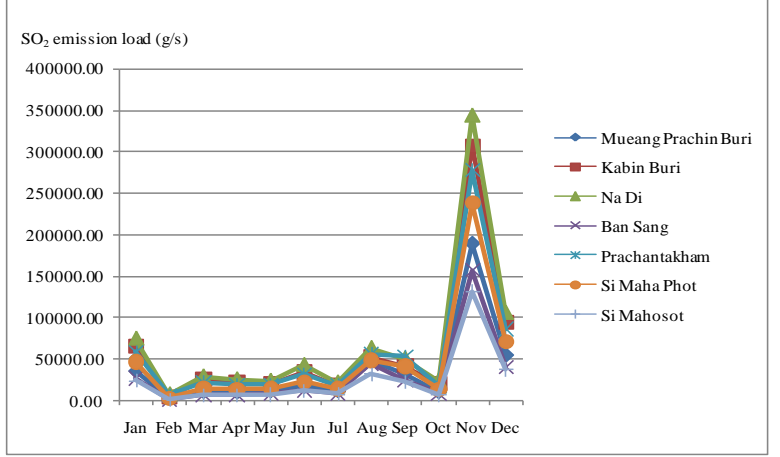

Fig. 8. $\mathrm{SO}_{2}$ Emission load of Prachinburi

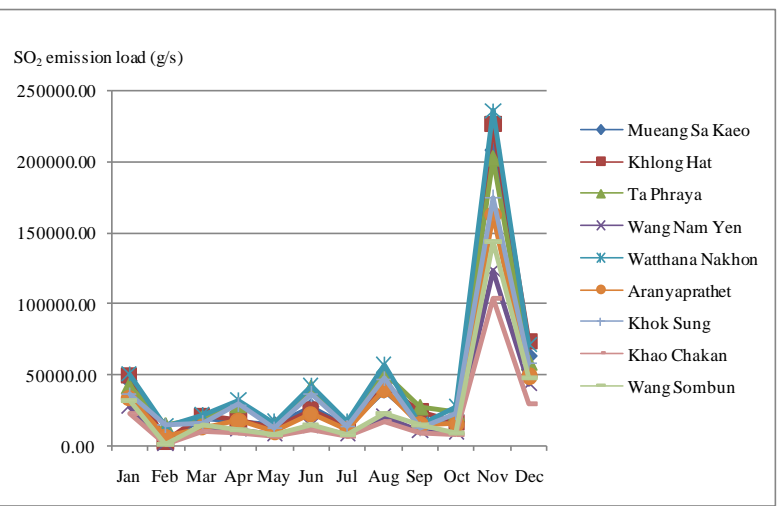

Fig. 9. $\mathrm{SO}_{2}$ Emission load of Sa Kaeo.

\section{B. $\mathrm{NO}_{2}$ Emission load}

Results from the box model analysis indicated that there were spatial and temporal variations of carrying capacity of $\mathrm{NO}_{2}$ emission in the study area.

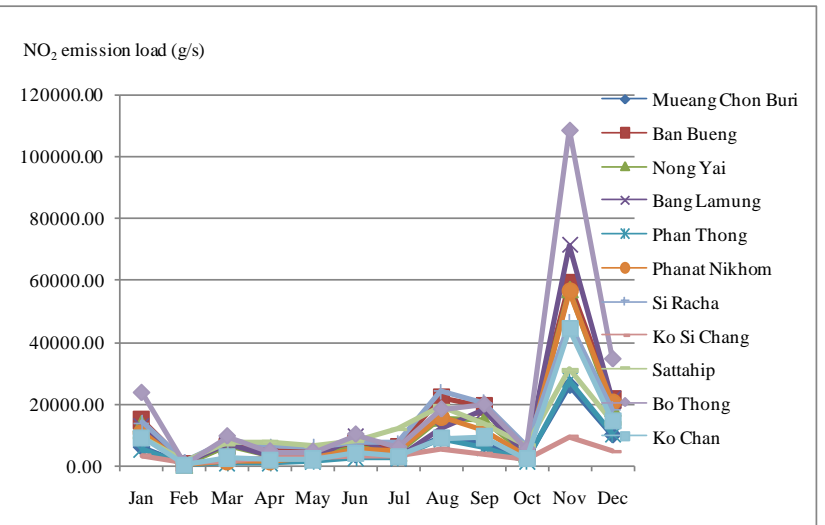

Fig. 10. $\mathrm{NO}_{2}$ Emission load of Chonburi.

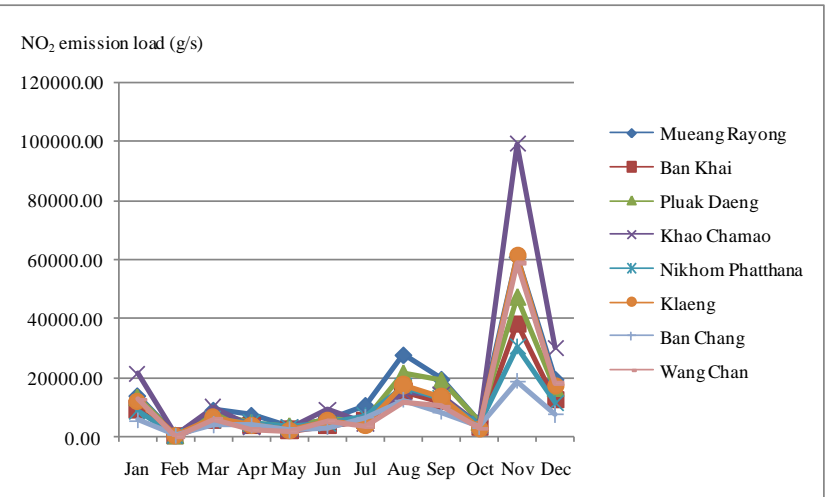

Fig. 11. $\mathrm{NO}_{2}$ Emission load of Rayong.

In general, it was found that Chachaengsao province has 
the highest assimilative capacity of $\mathrm{NO}_{2}$ as compared with other provinces. Temporal variation of the highest assimilative capacity was occurred in November. Details were as displayed in Fig. 10-16.

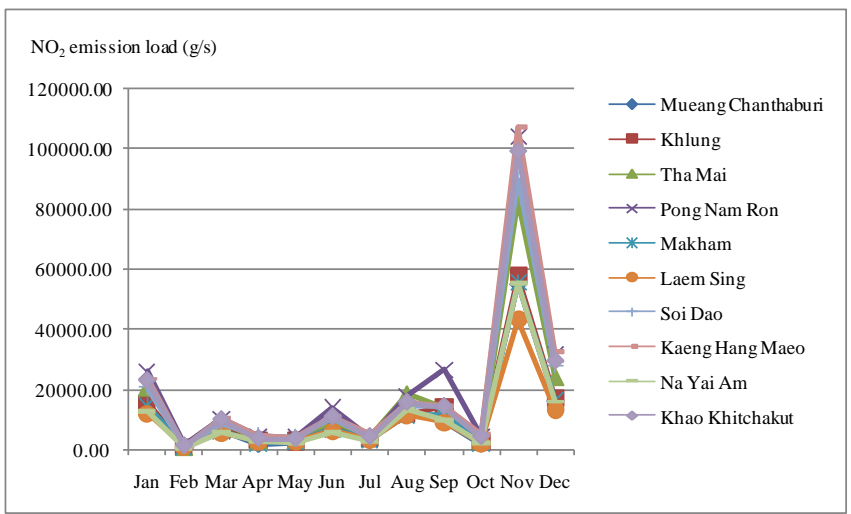

Fig. 12. $\mathrm{NO}_{2}$ Emission load of Chanthaburi.

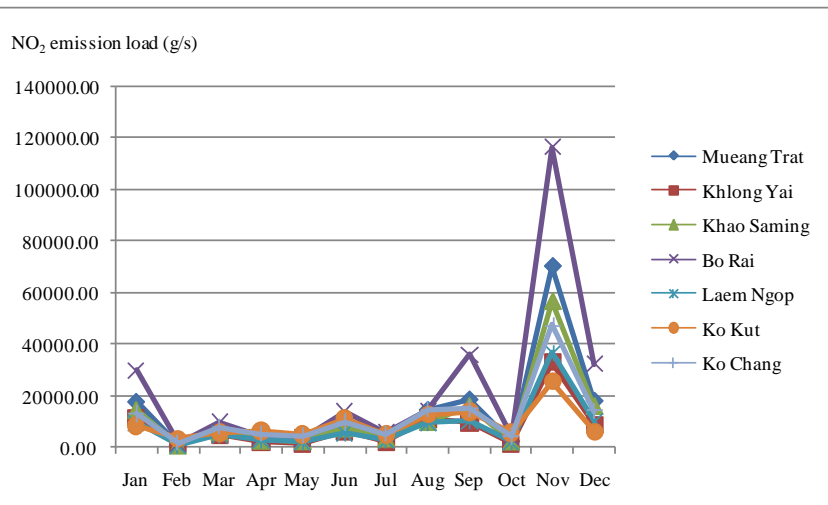

Fig. 13. $\mathrm{NO}_{2}$ Emission load of Trat.

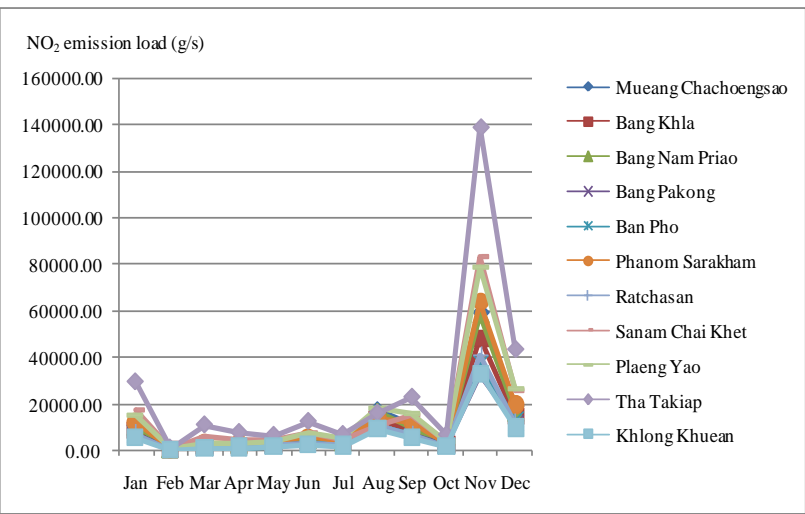

Fig. 14. $\mathrm{NO}_{2}$ Emission load of Chachaengsao.

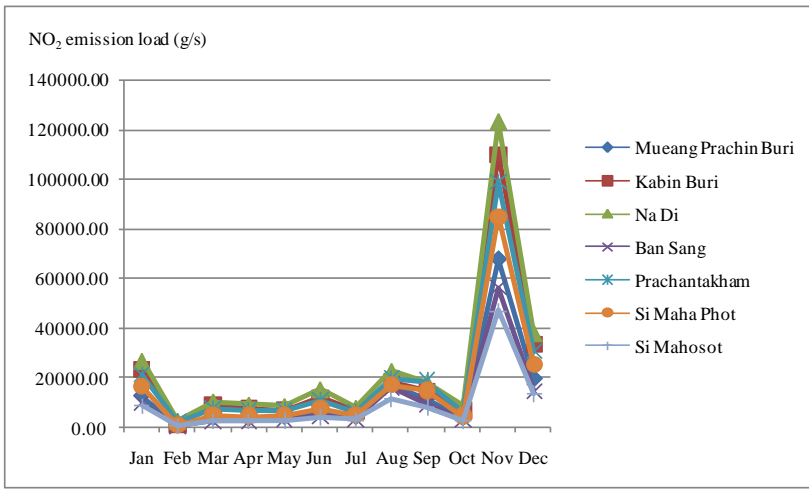

Fig. 15. $\mathrm{NO}_{2}$ Emission load of Prachinburi.

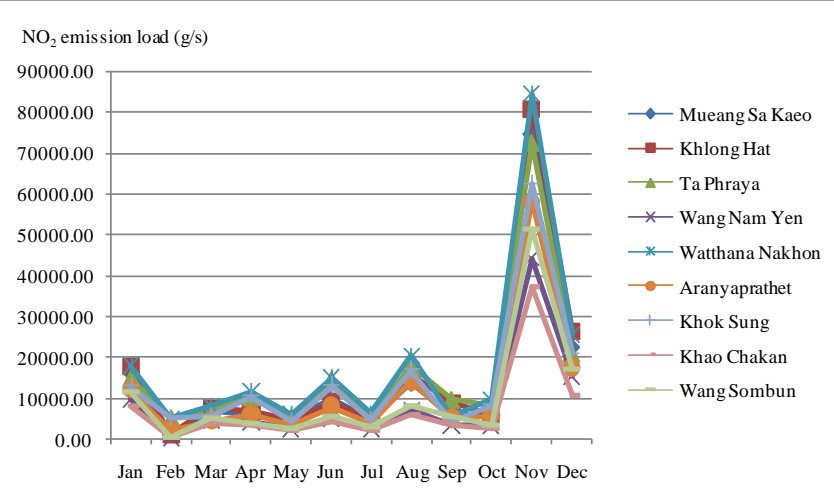

Fig. 16. $\mathrm{NO}_{2}$ Emission load of Sa Kaeo.

\section{CONCLUSIONS}

The assimilation potential in terms of the emission load was been estimated for the Eastern region of Thailand using box model. The results indicated that the assimilation potential of the atmosphere is directly proportional to the ventilation coefficient and has been computed using meteorological parameters for each month of the years 2010.

Spatial analysis of these data displayed that the highest assimilative capacity of $\mathrm{SO}_{2}$ and $\mathrm{NO}_{2}$ was at Tha-Takiap, Chachaengsao. This area is high atmospheric dilution ability because there are large area and high ventilation coefficient.

The results showed that temporal variation of assimilative capacity of air pollution in the study area in which the highest carrying capacity was in November. This is due to the influence of the northeast monsoon resulting in high dilution ability of atmosphere during this time.

\section{REFERENCES}

[1] S. K. Goyal and C. V. C. Rao, "Air assimilative capacity-based environment friendly siting of new industries - A case study of Kochi region, India," Journal of Environmental Management, vol. 84, pp. 473-483, 2007.

[2] Clean Air Initiative for Asian Cities (CAI-Asia) Center, Thailand: Air Quality Profile 2010 Edition; Philippines, 2010, pp. 6.

[3] P. Goyal, S. Anand, and B. S. Gera, "Assimilative capacity and pollutant dispersion studies for Gangtok city," Atmospheric Environment, vol. 40, pp. 1671-1682, 2006.

[4] S. Thepanondh, "Assessment of air assimilstive capacity of Thailand: case study of sulfur dioxide and nitrogen dioxide," Thailand, 2013.

[5] F. Murena, "Monitoring and modelling carbon monoxide concentrations in a deep street canyon: application of a two-box model," Atmospheric Pollution Research, vol. 3, pp. 311-316, 2012.

[6] P. N. Ho, D. N. Bach, and V. V. Manh, "Applying Fixed Box Model to Calculate the Temporal Variance of the Concentration of PM10 in Thanh Xuan District, Hanoi (Vietnam)," in Environmental Informatics and Industrial Environmental Protection: Concepts, Methods and Tools, Germany: Shaker Verlag, 2009, pp. 157-165.

[7] N. D. Nevers, Thailand: Air Pollution Control Engineering; Singapore: McGraw-Hill Book Co, 2000, pp. 120-122.

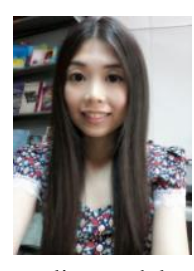

Jaeraya Ruangkawsakun is from Thailand and she was born in 1987. She received the bachelor's degree of Science (Environmental Science) from Kasetsart University in 2009 and the bachelor's degree of Public Health (Occupational Health and Safety) from Sukhothai Thammathirat Open University in 2012. Currently, she is pursuing master of Science (Environmental Technology) from Mahidol University. Her research interest is air 